\title{
AMELIORATION OF OLANZAPINE-INDUCED IMPAIRED GLUCOSE TOLERANCE IN MICE WITH METHANOL EXTRACT OF STEAMED Brassica oleracea (CABBAGE) LEAVES
}

\author{
FARJANA AKTHER NOOR ${ }^{1}$, SONGJUKTA CHAKRABORTY ${ }^{2}$, CHRISTOPHE WIART $^{3}$ \\ AND MOHAMMED RAHMATULLAH ${ }^{2 *}$ \\ ${ }^{1}$ Department of Biotechnology \& Genetic Engineering, \\ University of Development Alternative, Dhaka, Bangladesh \\ ${ }^{2}$ Department of Pharmacy, University of Development Alternative, Dhaka, Bangladesh \\ ${ }^{3}$ School of Pharmacy, University of Nottingham Malaysia Campus, Semenyih, Malaysia
}

Published online: 30 November 2020

To cite this article: FARJANA AKTHER NOOR, SONGJUKTA CHAKRABORTY, CHRISTOPHE WIART \& MOHAMMED RAHMATULLAH (2020) Amelioration of olanzapineinduced impaired glucose tolerance in mice with methanol extract of steamed Brassica oleracea (cabbage) leaves, Malaysian Journal of Pharmaceutical Sciences, 18(2): 73-78, https://doi.org/10.21315/mjps2020.18.2.6

To link to this article: https://doi.org/10.21315/mjps2020.18.2.6

Olanzapine is an antipsychotic drug and has been reported to induce impaired glucose tolerance leading to high blood glucose levels. In oral glucose tolerance tests (OGTT), methanolic extract of steamed cabbage (Brassica oleracea L. var. capitata) (MEBO) leaves have been shown to reduce elevated blood glucose levels in glucose-loaded mice. It was thus of interest to determine whether MEBO leaves can ameliorate olanzapineinduced impaired glucose tolerance in mice, which have been administered olanzapine for 28 days. Impaired glucose tolerance was measured through OGTT in mice. Olanzapine (28 days)-administered mice showed elevated blood glucose in OGTT. MEBO leaves showed significant reduction of blood glucose level in OGTT in mice (compared to vehicle or olanzapine treated mice for 28 days, Groups 2 and 3, respectively) both when administered for 28 days along with olanzapine, as well when administered 60 min prior to glucose loading in OGTT (positive control glibenclamide administered at $10 \mathrm{mg} / \mathrm{kg}$ ). A single dose of MEBO (400 mg/kg) was used based on previous studies. Thus, MEBO leaves can be beneficial for improving glucose tolerance and reduce blood glucose levels in olanzapine-induced elevated blood glucose levels.

Keywords: Olanzapine, OGTT, Cabbage, Mice

\section{INTRODUCTION}

Type 2 diabetes mellitus and impaired glucose tolerance are associated with antipsychotic treatment. The strength of the association between antipsychotics and impaired glucose tolerance varies across individual medications, with the largest number of reports for

"Corresponding author: rahamatm@hotmail.com

(C) Penerbit Universiti Sains Malaysia, 2020. This work is licensed under the terms of the Creative Commons Attribution (CC BY) (http://creativecommons.org/licenses/by/4.0/). 
chlorpromazine, clozapine, and olanzapine (Haupt and Newcomer 2001). In a previous study we have shown that chronic oral administration of olanzapine $(100 \mathrm{mg} / \mathrm{kg}$ body weight for 28 days) can induce glucose intolerance in mice (Noor, Hossain and Rahmatullah 2016). In another study it has been shown that methanol extract of steamed Brassica oleracea L. var. capitata (cabbage) (MEBO) leaves can improve glucose tolerance in glucose-loaded mice, and so lower blood glucose levels in oral glucose tolerance test or OGTT (Akther et al. 2016). It was, thus, of interest to evaluate the potential of MEBO to ameliorate glucose intolerance induced by olanzapine in mice.

\section{METHODS}

\section{Chemicals and Drugs}

Olanzapine was obtained from Sigma Chemical Co., USA; glibenclamide and glucose were obtained from Square Pharmaceuticals Ltd., Bangladesh. All other chemicals were of analytical grade. Methanol and dimethyl sulfoxide (DMSO) were obtained from Merck (Germany). Olanzapine was dissolved in DMSO prior to oral gavaging in mice.

\section{Animals}

Swiss albino mice, which weighed between $15 \mathrm{~g}$ and $19 \mathrm{~g}$ were used in the present study. The animals were obtained from the International Centre for Diarrhoeal Disease Research (ICDDR), Bangladesh. The animals were acclimatised for 3 days prior to actual experiments; the actual experiments were conducted over a period of 4 weeks where the mice were supplied with normal mice chow (obtained from ICDDR, B) and water ad libitum. Experimental mice received olanzapine dissolved in $1 \%$ DMSO by gavaging every day during this time period (4 weeks).

\section{Collection of Cabbage and Preparation of Leaf Extract}

Cabbage was bought from a local market in Dhaka, Bangladesh. The plant was identified at the Bangladesh National Herbarium with accession number of 39513 . MEBO leaves were done as described earlier.

\section{Oral Glucose Tolerance Tests}

OGTT were carried out as previously described (Joy and Kuttan 1999). Briefly, mice were grouped into 6 groups of 5 mice each (Groups 1-6) and OGTT was performed on Groups 2-6 mice. The various groups received different treatments like Group 1 received just mice chow and water ad libitum for 28 days. Group 1 mice were fasted for $16 \mathrm{~h}$ after 28 days and then sacrificed followed by measurement of blood glucose (considered as fasting basal blood glucose level). Groups 2-6 mice received mice chow and water ad libitum for 28 days. Group 2 also received vehicle (1\% DMSO) during this 28 day time period and served as control. Groups 3-6 received olanzapine (100 mg/kg body weight/ day) for the same time period (28 days). Group 4 mice received MEBO (400 mg per $\mathrm{kg}$ body weight/day) additionally with olanzapine. After 28 days, Groups 2-6 mice were fasted for $16 \mathrm{~h}$ followed by administration of vehicle (Groups $2-4$ ), glibenclamide (10 mg/kg body weight) to Group 5 and MEBO (400 $\mathrm{mg} / \mathrm{kg}$ body weight) to Group 6 . In the experiment, a

Malay J Pharm Sci, Vol. 18, No. 2 (2020): 73-78 
single dose of MEBO (400 mg/kg) was used based on previous studies (Akther et al. 2016). All substances, i.e. vehicle, glibenclamide and extract (MEBO) were orally administered. Following a period of $1 \mathrm{~h}$, Groups 2-6 mice were orally administered $2 \mathrm{~g}$ glucose $/ \mathrm{kg}$ of body weight. Blood glucose levels were measured 120 min after glucose administration with a glucometer (Islam et al. 2009). The percent lowering of blood glucose levels were calculated according to the formula described below.

Percent lowering of blood glucose level $=\left(1-\mathrm{W}_{\mathrm{e}} / \mathrm{W}_{\mathrm{c}}\right) \times 100$,

where $W_{e}$ and $W_{c}$ represents the blood glucose concentration in experimental (Groups 3-6) mice and control mice (Group 2), respectively.

\section{Statistical Analysis}

Experimental values are expressed as mean \pm SEM. Independent sample $t$-test was carried out for statistical comparison. Statistical significance was considered to be indicated by a $p$-value $<0.05$ in all cases (Hossain et al. 2014).

\section{Ethical Approval}

The study was conducted following approval by the Institutional Animal Ethical Committee of University of Development Alternative, Dhaka, Bangladesh.

\section{RESULTS}

At the end of 28 days, Group 1 mice had blood glucose levels of $4.16 \pm 0.37 \mathrm{mmol} / \mathrm{L}$ (fasting basal blood glucose level, mean \pm SEM). In OGTT tests, Group 2 (that is glucoseloaded control mice) had elevated blood glucose levels of $5.80 \pm 0.16 \mathrm{mmol} / \mathrm{L}$. In Group 3 (olanzapine administered for 28 days), mice in OGTT demonstrated blood glucose levels of $7.30 \pm 0.15 \mathrm{mmol} / \mathrm{L}$, that is a $25.9 \%$ increase over Group 2 control mice (significant at $p<0.05$ ), in agreement with previous studies that chronic intake of olanzapine causes impaired glucose tolerance leading to elevated blood glucose levels (Noor, Hossain and Rahmatullah 2016). In Group 4 (olanzapine along with MEBO administered for 28 days), mice in OGTT tests showed blood glucose levels of $4.72 \pm 0.21 \mathrm{mmol} / \mathrm{L}$, suggesting that MEBO can ameliorate olanzapine-induced impaired glucose tolerance (Group 4 versus Group 3). Administration of glibenclamide (Group 5) or MEBO (Group 6) led to reductions of blood glucose levels in OGTT by $39 \%$ and $34.8 \%$, respectively. The results are shown in Table 1 and suggest that MEBO can possibly be as effective as an antihyperglycemic drug, glibenclamide in restoring impaired glucose tolerance and consequent hyperglycemia caused by olanzapine. 
Table 1: Effect of MEBO on blood glucose levels in OGTT in mice with olanzapine-induced elevated blood glucose levels.

\begin{tabular}{|c|c|c|c|}
\hline Experimental details & $\begin{array}{l}\text { Treatment and dose } \\
\text { (mg/kg body weight) }\end{array}$ & $\begin{array}{l}\text { Blood glucose } \\
\text { level (mmol/L) }\end{array}$ & $\begin{array}{l}\% \text { Change in blood } \\
\text { glucose level }\end{array}$ \\
\hline $\begin{array}{l}\text { Group } 1 \text { (fasting basal } \\
\text { blood glucose) }\end{array}$ & Vehicle (28 days) & $4.16 \pm 0.37$ & Not applicable \\
\hline Group 2 (OGTT) & Vehicle (28 days) & $5.80 \pm 0.16$ & 0 \\
\hline Group 3 (OGTT) & $\begin{array}{l}100 \mathrm{mg} \text { olanzapine } \\
\text { (28 days) }\end{array}$ & $7.30 \pm 0.15$ & $+25.9^{*}$ \\
\hline Group 4 (OGTT) & $\begin{array}{l}100 \text { mg olanzapine } \\
\text { (28 days) }+400 \mathrm{mg} \\
\text { MEBO ( } 28 \text { days) }\end{array}$ & $4.72 \pm 0.21$ & $-18.6^{*}$ \\
\hline Group 5 (OGTT) & $\begin{array}{l}100 \mathrm{mg} \text { olanzapine } \\
(28 \text { days })+ \\
\text { glibenclamide (10 mg/ } \\
\mathrm{kg}, 1 \mathrm{~h} \text { before glucose } \\
\text { administration) }\end{array}$ & $3.54 \pm 0.13$ & $-39.0^{*}$ \\
\hline Group 6 (OGTT) & $\begin{array}{l}100 \mathrm{mg} \text { olanzapine } \\
\text { (28 days) + MEBO } \\
\text { (400 mg/kg, } 1 \mathrm{~h} \\
\text { before glucose } \\
\text { administration) }\end{array}$ & $3.78 \pm 0.06$ & $-34.8^{*}$ \\
\hline
\end{tabular}

Notes: All administrations were made orally. Values represented as mean \pm SEM, $(n=5)$; ${ }^{*} p<0.05$; significant compared to hyperglycemic control animals (Group 2).

\section{DISCUSSION}

It is to be noted that since MEBO was efficient in lowering olanzapine-induced elevated blood glucose level in mice in the present study, it is possible that it may prove beneficial to patients undergoing treatment with olanzapine. Cabbage is known to contain $\beta$-sitosterol, chlorogenic acid, ferulic acid, kaempferol and quercetin (Duke 1992). It is worthwhile to explore the effects of these individual ingredients in olanzapine treated mice, for a number of these compounds have reported blood glucose lowering efficacies (Oboh et al. 2015; Varghese, Bose and Habtemariam 2013; Karan et al. 2012; Alkhalidy et al. 2015; Aguirre et al. 2011).

\section{CONCLUSION}

Cabbage leaves may be potential sources of new drugs to improve impaired glucose tolerance.

\section{ACKNOWLEDGEMENTS}

This work was funded through internal funding of the University of Development Alternative.

Malay J Pharm Sci, Vol. 18, No. 2 (2020): 73-78 


\section{REFERENCES}

AGUIRRE, L., ARIAS, N., MACARULLA, M. T., GRACIA, A. \& PORTILLO, M. P. (2011) Beneficial effects of quercetin on obesity and diabetes, The Open Nutraceuticals Journal, 4: 189-198. https://doi.org/10.2174/1876396001104010189

AKTHER, M., ISLAM, E., ISLAM, M. T., DAS, P. R., HAQUE, M. E., JAHAN, R. et al. (2016) A preliminary study on significant antihyperglycemic activity as determined through oral glucose tolerance tests of three common plants belonging to the Brassicaceae family, World Journal of Pharmacy and Pharmaceutical Sciences, 5: 159-172.

ALKHALIDY, H., MOORE, W., ZHANG, Y., MCMILLAN, R., WANG, A., ALI, M. et al. (2015) Small molecule kaempferol promotes insulin sensitivity and preserved pancreatic $\beta$-cell mass in middle-aged obese diabetic mice, Journal of Diabetes Research, 2015: Article ID: 532984. https://doi.org/10.1155/2015/532984

DUKE, J. A. (1992). Handbook of phytochemical constituents of GRAS herbs and other economic plants. (Boca Raton, FL.: CRC Press).

HAUPT, D. W. \& NEWCOMER, J. W. (2001) Hyperglycemia and antipsychotic medications, Journal of Clinical Psychiatry, 62 (Suppl 27): 15-26.

HOSSAIN, A. I., FAISAL, M., RAHMAN, S., JAHAN, R. \& RAHMATULLAH, M. (2014) A preliminary evaluation of antihyperglycemic and analgesic activity of Alternanthera sessilis aerial parts, BMC Complementary and Alternative Medicine, 14: 169-173. https://doi. org/10.1186/1472-6882-14-169

ISLAM, M. A., AKHTAR, M. A., KHAN, M. R. I., HOSSAIN, M. S., ALAM, A. H. M. K., WAHED, M. I. I. et al. (2009) Oral glucose tolerance test (OGTT) in normal control and glucose induced hyperglycemic rats with Coccinia cordifolia L. and Catharanthus roseus L., Pakistan Journal of Pharmaceutical Sciences, 22: 402-404.

JOY, K. L. \& KUTTAN, R. J. (1999) Anti-diabetic activity of Picrorrhiza kurroa extract, Journal of Ethnopharmacology, 67(2): 143-148. https://doi.org/10.1016/S0378-8741(98)00243-8

KARAN, S. K., MISHRA, S. K., PAL, D. \& MONDAL, A. (2012) Isolation of $\beta$-sitosterol and evaluation of antidiabetic activity of Aristolochia indica in alloxan-induced diabetic mice with a reference to in-vitro antioxidant activity, Journal of Medicinal Plants Research, 6: 12191223. https://doi.org/10.5897/JMPR11.973

NOOR, F. A., HOSSAIN, M. N. \& RAHMATULLAH, M. (2016) Chronic administration of olanzapine (an antidepressant drug) leads to impaired glucose tolerance in mice, World Journal of Pharmacy and Pharmaceutical Sciences, 5: 214-220.

OBOH, G., AGUNLOYE, O. M., ADEFEGHA, S. A., AKINYEMI, A. J. \& ADEMILUYI, A. O. (2015) Caffeic and chlorogenic acids inhibit key enzymes linked to type 2 diabetes (in vitro): A comparative study, Journal of Basic and Clinical Physiology and Pharmacology, 26(2): 165-170. https://doi.org/10.1515/jbcpp-2013-0141 
VARGHESE, G. K., BOSE, L. V. \& HABTEMARIAM, S. (2013) Antidiabetic components of Cassia alata leaves: Identification through a-glucosidase inhibition studies, Pharmaceutical Biology, 51(3): 345-349. https://doi.org/10.3109/13880209.2012.729066 